\title{
MORPHOLOGICAL EFFECTS OF COMBINED SYSTEMIC ADMINISTRATION OF FLUOXETINE AND SILDENAFIL IN THE MURINE HIPPOCAMPUS
}

\author{
Received July 20, 2012.
}

\begin{abstract}
We examined the effects of fluoxetine, a selective serotonin re-uptake inhibitor, of sildenafil, a phosphodiesterase-5 (PDE5) inhibitor, and of combined administration of these agents on morphometric characteristics of principal cells of the murine hippocampus. Fluoxetine $(5 \mathrm{mg} / \mathrm{kg})$, sildenafil $(2 \mathrm{mg} / \mathrm{kg})$, or a combination of these drugs in the above doses were administered i.p. daily for 2 weeks to male mice. Hippocampal sections ( $5 \mu \mathrm{m}$ thick) were stained with hematoxylin/eosin. Both drugs and their combination evoked no considerable changes in the dimensions of pyramidal cells in the CA1 and CA2 areas and in the dentate gyrus (DG), except for a trend toward some decrease of this parameter after fluoxetine injections in the $C A 1$ area. Combined administration of fluoxetine and sildenafil provided significant decreases in the density of pyramidal neurons (their mean number per $10 \mu \mathrm{m}$ of the slice) in the $C A 1$ area and DG. Isolated administration of fluoxetine resulted in significant but less intense decreases in the density of principal cells in the CA2 area and DG. Possible mechanisms of the effects of the mentioned drugs are discussed. Further studies of interaction between fluoxetine and sildenafil in their effects on morphological and physiological properties of cells in different subregions of the hippocampus are recommended.
\end{abstract}

Keywords: hippocampus, principal cells, fluoxetine, sildenafil, mice.

\section{INTRODUCTION}

The hippocampus is an important brain structure that is a target for a number of drugs [1]. Hippocampal neuronal systems are involved in various physiological functions, such as anxiety, depression [2], cognition, learning, and memory [3, 4]. It is well known that the hippocampus is one of the crucial cerebral regions related to behavior, and its behavior-controlling functions are affected by many neuroactive drugs [1, 2, 4-6]. In the CNS of mammals, the hippocampus is one of the oldest brain regions from the phylogenetic aspect. It consists of two major parts, the hippocampus per se (Ammon's horn, or cornu ammonis, CA) and the dentate gyrus (DG) [2, 7-9]. The hippocampus proper

\footnotetext{
${ }^{1}$ Department of Biology, School of Basic Sciences, Islamic Azad University, Hamedan Branch, Hamedan, Iran.

${ }^{2}$ Neurophysiology Research Center, Hamadan University of Medical Sciences, Hamadan, Iran.

Correspondence should be addressed to N. Hashemi-Firouzi

(e-mail: nhashemifirozi@yahoo.com).
}

includes three subregions, areas $C A 1-C A 3[8,9]$.

Fluoxetine, a selective serotonin re-uptake inhibitor (SSRI) and a known antidepressant, is commonly used in psychiatry [2]. It was found that this agent improves cell proliferation and neurogenesis in the hippocampus $[1,6]$. The effects of fluoxetine have been reported with respect to such activities as synaptogenesis of pyramidal cells [2], plasticity of astrocytes [7], expression of synaptic proteins [10], and elevation of the spine density in the $C A 1$ area and DG of the hippocampus [8].

On the other hand, sildenafil, a phosphodiesterase-5 (PDE5) inhibitor, that easily penetrates the CNS, increases the cGMP level $[3,11]$. Sildenafil intensifies neurogenesis and promotes functional recovery after ischemia [12, 13], induces angiogenesis [12], and increases the number of varicosities in the $C A 3$ region of the hippocampus [4]. In addition, sildenafil is useful for reversing sexual dysfunction resulting from SSRI actions, including fluoxetine [14, 15]. The efficacy of combined treatment by fluoxetine and sildenafil in anxiety, depression, and fertility disorders has been reported [11, 14-16]; recent studies 
indicated that nitric oxide synthase (NOS) activity in the hippocampus mediates the effect of fluoxetine in mice [17].

Considering the beneficial functional effects of fluoxetine and sildenafil mentioned above, our study was undertaken to examine the effects of systemic administration of fluoxetine and sildenafil and their co-administration on morphological characteristics of principal neuronal components of the murine hippocampus.

\section{METHODS}

Animals. Experimental N-MARI male mice (30 to $35 \mathrm{~g}$; $n=20$ ) were obtained from the breeding colony of the Iran Pasteur Institute (Tehran) and randomly distributed into four groups (five animals in each). Mice were housed at a constant temperature of $20 \pm 2{ }^{\circ} \mathrm{C}$ with a 12:12 h light/dark cycle (lights on at 7:00 a.m) with free access to food and water ad libitum.

Drug Treatment. One week after acclimatization, experimental mice were i.p. treated with fluoxetine ( $5 \mathrm{mg} / \mathrm{kg}$; Tocris, Great Britain), sildenafil (2 mg/kg; Vorin, India), or a combination of these drugs in the above doses once a day for 15 consecutive days [2]. Control animals received a vehicle. The drugs were freshly prepared each day in physiological saline. The doses of drugs were calculated according to the baseline weight of each animal.

Experimental Procedure. The mice were anesthetized by a mixture of xylasine/ketamine $3 \mathrm{~h}$ after the last drug or vehicle injection [2], transcardially perfused with $0.9 \%$ saline followed by formalin, and decapitated. The brains were immediately removed, post-fixed in fresh Bouin solution for at least 7 days, and embedded in paraffin. Using a rotatory microtome, serial coronal sections of the brain ( $5 \mu \mathrm{m}$ thick) were cut through the entire hippocampus. A stereotaxic brain atlas [9] was used for reference during sectioning procedures. After standard dehydration, fixation, embedding into paraffin, and deparaffinization procedures, the sections were stained using a standard hematoxylin/eosin technique. Slices were examined at a $400 \times$ magnification under a BA 400 microscope (Motic, Spain) equipped with a camera output to a computer monitor. The images were stored using the respective software and assembled using brightness at a level of +50 . In the coronal sections of the hippocampus, the number (density) of principal neurons, their dimension, and thickness of the pyramidal layer were measured in the $C A 1, C A 2$, and $C A 3$ regions and also in the DG. The alteration of the neurons was estimated with the optical dissector following a fractionator principle [7].

Statistical Analyses. All numerical data are shown as means \pm s.e.m. The significance of intergroup differences was calculated by one-way ANOVA followed by the post-hoc Tukey test for multiple comparisons. The statistical significance was defined at $P<0.05$.

\section{RESULTS}

Figure 1 illustrates the effects of fluoxetine, sildenafil, or a combination of these agents on the dimension of principal cells in the $C A 1, C A 2$, and DG subfields of the hippocampus. As can be seen, isolated introductions of fluoxetine led to some trend to toward a decrease in this parameter in the CA1 area (Fig. 1A). Nonetheless, one-way ANOVA showed that differences between the mean dimensions of principal cells in the mentioned hippocampal regions related to both isolated and combined treatment with the above agents did not reach the level of significance.

Figure 2 illustrates the effects of drug treatment on the density of principal cells in three regions of the hippocampus under study. One-way ANOVA revealed significant differences between the effects in the groups. The Tukey-Kramer test showed that a combination of fluoxetine and sildenafil provided significant decreases in the density of principal cells (their mean number per $10 \mu \mathrm{m}$ of the slice) in the $C A 1$ area and DG $(P<0.01, \mathrm{~A}, \mathrm{C})$. It should be mentioned that isolated introductions of fluoxetine induced considerable decreases in the cell density in the $C A 2$ area and DG $(P<0.05$ and $P<0.01$, respectively, $\mathrm{B}, \mathrm{C})$. At the same time, isolated action of sildenafil did not evoke significant changes in the density of principal cells in all the regions examined (only mild insignificant trends toward decrease could be noticed; A-C). Upon the combined action of the abovementioned agents, the cell density in the $C A 2$ area was practically similar to that in the control (B).

In Fig. 3, photomicrographs of slices of the $C A 1$, $C A 2$, and DG regions of the hippocampus of mice treated for 2 weeks with fluoxetine, sildenafil, and a combination of fluoxetine and sildenafil or vehicle are shown. 

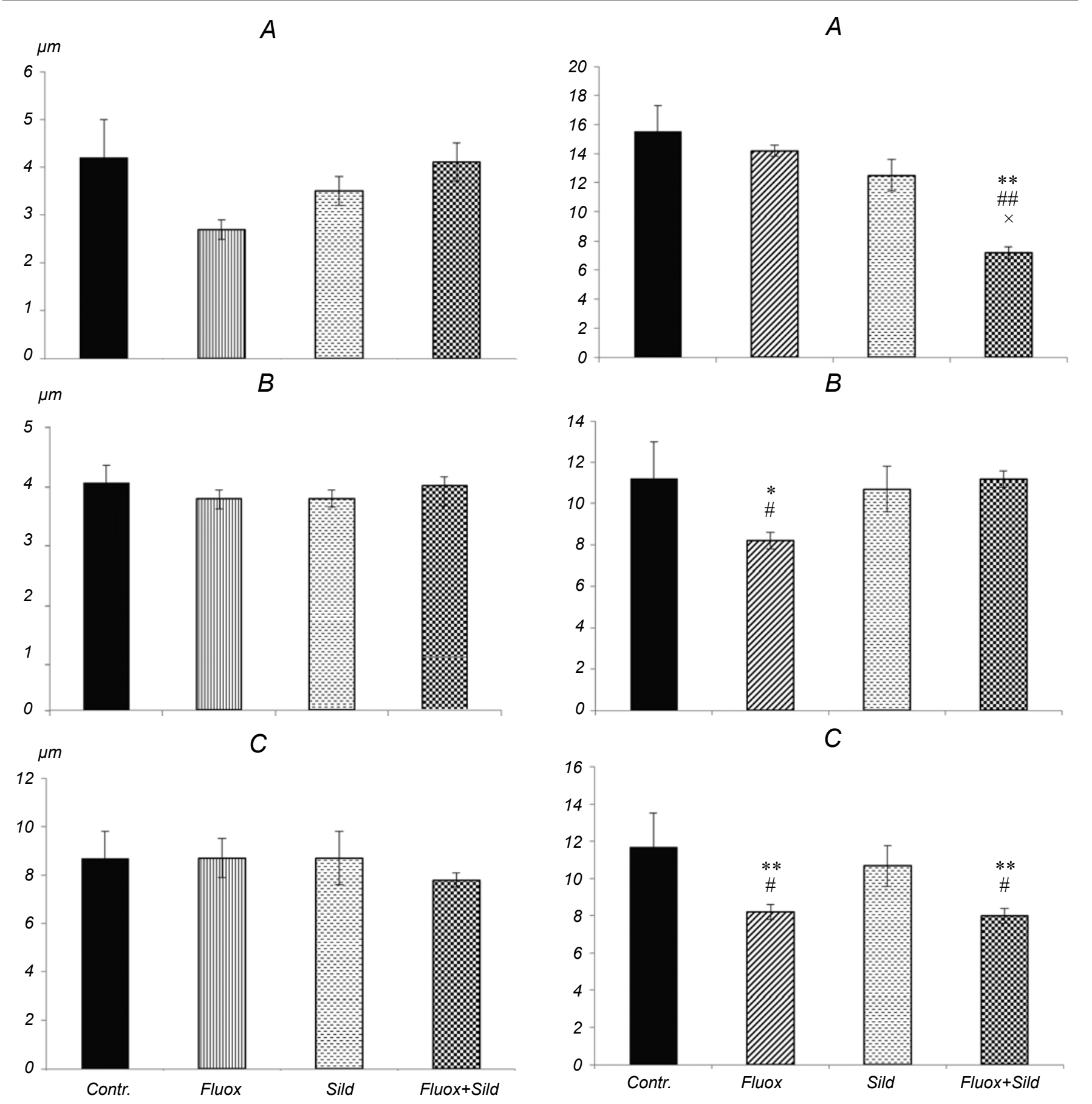

F i g. 1. Mean dimensions (diameters, $\mu \mathrm{m}$ ) of principal (pyramidal) cells in the $C A 1$ area, $C A 2$ area, and dentate gyrus (DG) of the hippocampus (A-C, respectively) of mice treated for 2 weeks with fluoxetine (Fluox), sildenafil (Sild), and their combination. Contr. is the control group. Means \pm s.e.m. are shown.

Р и с. 1. Середні розміри (діаметр, мкм) головних (пірамідних) клітин у зонах $C A 1$ та $C A 2$ і в зубчастій звивині гіпокампа $(A-C$ відповідно) мишей, яким уводили флуоксетин, силденафіл або їх комбінацію.

F i g. 2. Mean densities (numbers per $10 \mathrm{~mm}$ of the slice) of pyramidal cells in the $C A 1$ area, $C A 2$ area, and dentate gyrus of the hippocampus (A-C, respectively) of mice treated with fluoxetine (Fluox), sildenafil (Sild), and their combination. $* * P<$ 0.01 compared to the control group, $\# \# P<0.01$ compared to the Fluox group, and $\times P<0.05$ compared to the Sild group. Other designations are similar to those in Fig. 1.

Р и с. 2. Середні щільності (кількість на 10 мкм зрізу) пірамідних нейронів у зонах $C A 1$ та $C A 2$ і в зубчастій звивині гіпокампа ( $A-C$ відповідно) мишей, яким уводили флуоксетин, силденафіл або їх комбінацію. 


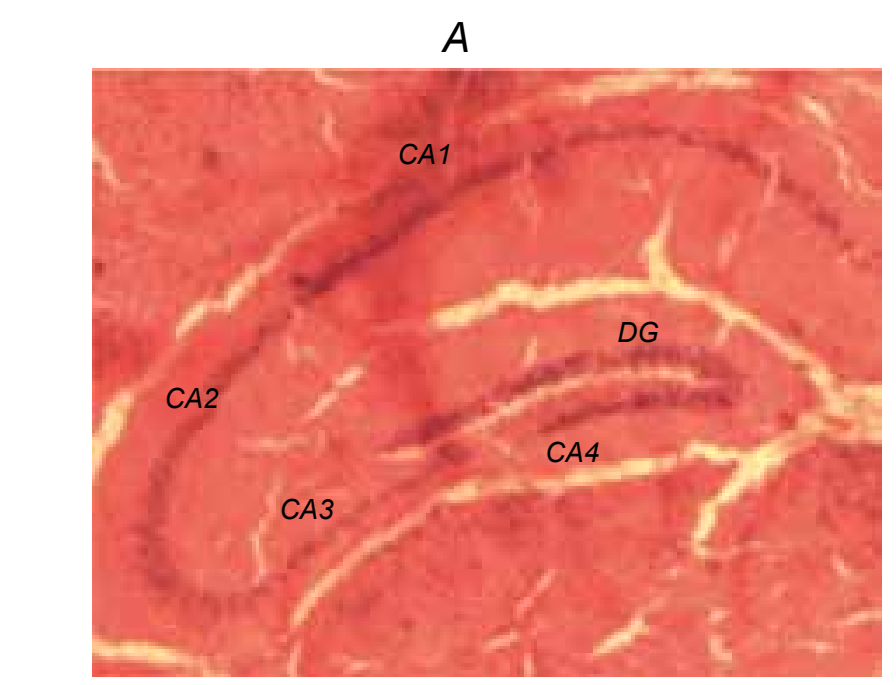

F i g. 3. Photomicrographs of hematoxylin/ eosin-stained slices of the hippocampus. A) At a low magnification, B) at a high magnification. Regions of the hippocampus are shown at the left; designations of the groups similar to those in Figs. 1 and 2 are shown above.

P и с. 3. Мікрофотографії зрізів гіпокампа (забарвлення гематоксиліном/еозином).

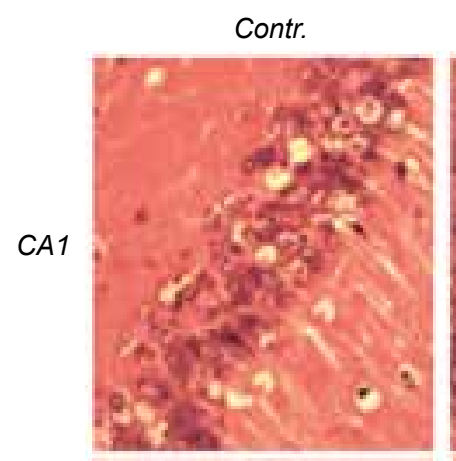

$B$
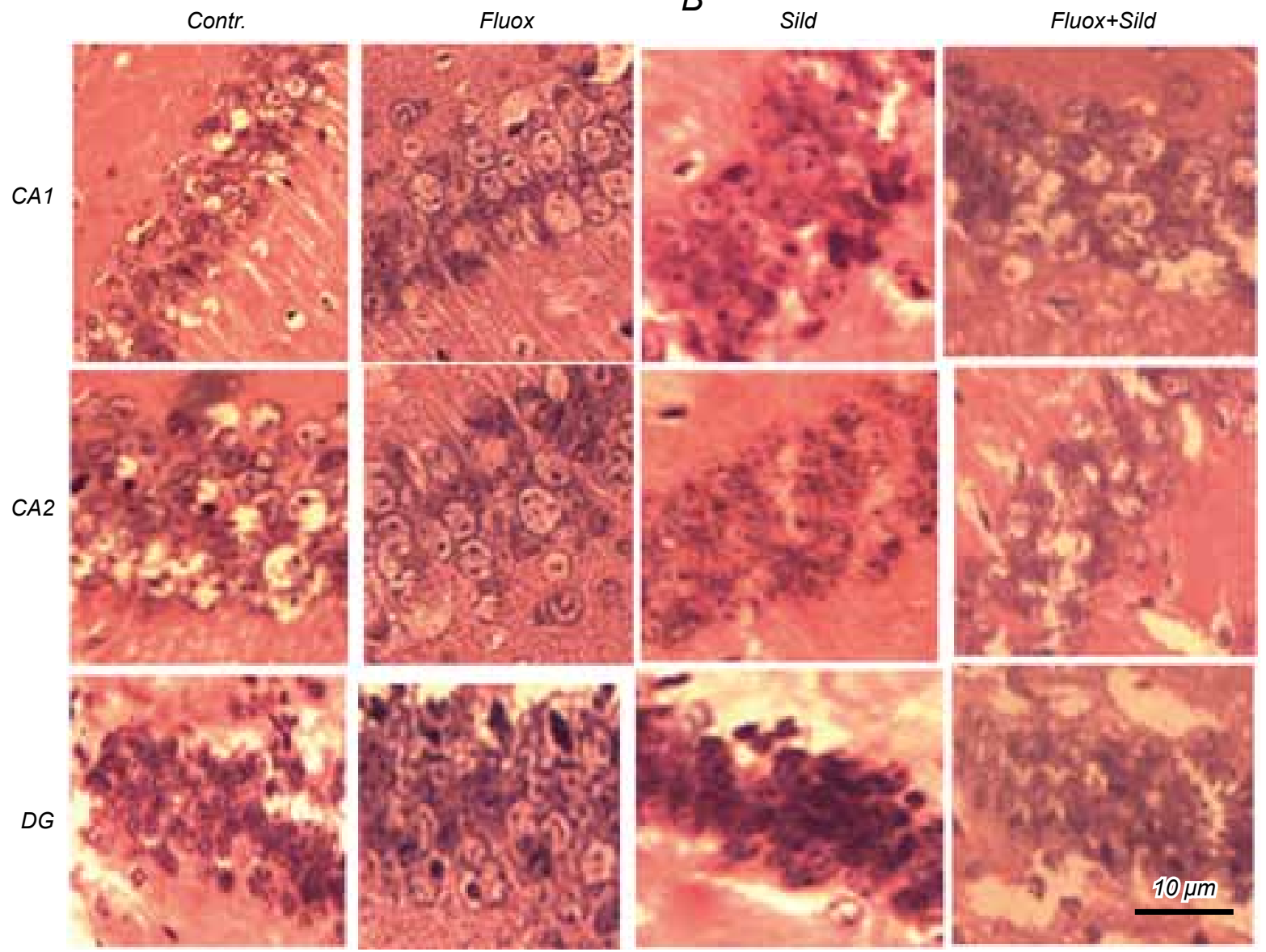

\section{DISCUSSION}

In this study, we evaluated counts and dimensions of principal neurons in the $C A 1, C A 2$, and DG regions of the hippocampus after two weeks of treatment with fluoxetine, sildenafil, or a combination of these agents.

Fluoxetine inhibits SERT activity and increases

extracellular levels of serotonin [2]. Serotonin is known to regulate neurogenesis and cell proliferation and to facilitate the growth of neurons [1, 2, 6, 7]. An increasing serotonin level resulting from chronic administration of fluoxetine considerably affects the hippocampus [1, 6, 7]. Possible mechanisms of the effect of fluoxetine (an SSRI antidepressant) might 
be attributed to changes in the level of neurotropic factors, neural growth, and synaptic plasticity [7]. In addition, previous studies demonstrated that treatment with fluoxetine promotes cell proliferation in the case of stress $[1,7]$ and increases neurogenesis and cell proliferation in the hippocampus $[1,6]$. Chronic administration of fluoxetine was reported to influence expression of several synaptic proteins [10], to intensify the process of synaptogenesis, and to restore the synaptic density in the hippocampus [2].

Sildenafil, which successfully crosses the bloodbrain barrier [18], inhibits PDE5 in the CNS [4]. The activity of guanylyl cyclase (GC), the enzyme that mediates production of cGMP, is known to be initiated by activation of NOS and increase in nitric oxide (NO) production [18]. A few experiments showed that sildenafil, as a selective PDE5 inhibitor, increases cGMP accumulation in the hippocampus [4]. The $\mathrm{NO} / \mathrm{cGMP}$ pathway mediates protein modifications [19]. In vitro studies demonstrated that high levels of cGMP modulate differentiation of stem cells into neurons [5]. Sildenafil, at the same time, exerts a protective effect against neurodegeneration, increases cell survival [5], induces an increase in the contents of a few proteins, and mediates a long-lasting neuroprotective effect of the hippocampus [12]. This PDE5 inhibitor enhances the cGMP levels in varicosities in the hippocampus [4]. Relatively mild effects of sildenafil found in our study are, probably, related to the duration of treatment, a relatively low dose of sildenafil, and peculiarities of the histological method used.

The hippocampus is rich with NOS and GC [20]. The NO-cGMP pathway has an important modulatory effect on the serotonergic system [17, 21]. Systemic administration of a NO inhibitor increases the efflux of serotonin in the hippocampus [21]. In serotonergic neurons, the serotonin re-uptake transporter (SERT) is co-localized with NOS [22]. Interaction between NOS and SERT negatively modulates SERT activity and increases nNOS activity and cGMP accumulation, thus enhancing serotonin re-uptake [20-22]. It seems possible that interaction between fluoxetine and sildenafil can provide the above effects.

Our results show that, in the case of relatively long ( 2 weeks) systemic administration, fluoxetine, sildenafil, and their combination exert certain effects on morphometric characteristics of principal cells in the murine hippocampus. With respect to the dimensions of pyramidal cells, the effects of these drugs, applied in any mode in the doses used, did not reach the level of significance (a trend toward a decrease in the mentioned parameter in the CAl area under the action on fluoxetine deserves, however, certain attention). At the same time, there were clear decreases in the number (density) of pyramidal cells in the $C A 1$ area and DG under conditions of combined treatment with fluoxetine and sildenafil. Thus, it seems that positive functional effects of a combination of these drugs [11, 14-16] can be accompanied by structural shifts in the hippocampus, which should be interpreted as negative from a certain aspect. At the same time, it should be mentioned that fluoxetine, when applied in an isolated mode, also led to decreases in the number of principal cells, but not in the same hippocampal zones (this effect was obvious in the $C A 2$ area and DG; Fig. 2B, C).

Thus, our study showed that chronic treatment with fluoxetine influences the regular arrangement of pyramidal neurons in some parts of the hippocampus. The effect of co-administration of fluoxetine and sildenafil with respect to the number (density) of these principal cells differs from that of fluoxetine applied in an isolated manner. The effects of fluoxetine and sildenafil on morphometric characteristics of pyramidal hippocampal neurons are not additive. These facts show that further research of the effects of systemic administration of these drugs in different subfields of hippocampus using morphological (morphometric), pharmacological, and physiological approaches is needed.

All experimental procedures and examination conditions were approved by the Committee of Islamic Azad University of Hamadan Branch and performed according to the Guide for Care and Use of Laboratory Animals published by the United States National Institutes of Health (NIH Publication No. 85-23, revised 1985).

There is no conflict of interest for any of the authors (M. Mahmoodi, S. Shahidi, N. Hashemi-Firouzi, and A. Komaki).

\section{M. Махмуді ${ }^{1}$, C. Шахіді ${ }^{2}$, Н. Хашемі-Фіроузі ${ }^{1}$, А. Комакі ${ }^{2}$}

ВПЛИВ СУКУПНИХ УВЕДЕНЬ ФЛУОКСЕТИНУ ТА СИЛДЕНАФІЛУ НА МОРФОЛОГІЧНІ ХАРАКТЕРИСТИКИ ГІПОКАМПА МИШЕЙ

\footnotetext{
${ }^{1}$ Відділ біології, факультет фундаментальних наук, Ісламський університет Азад, Хамадан (Іран).

${ }^{2}$ Нейрофізіологічний дослідницький центр, Хамаданський медичний університет, Хамадан (Іран).
} 
Р е $з$ ю м е

Ми досліджували вплив флуоксетину (селективного інгібітора зворотного захвату серотоніну), силденафілу (інгібітора фосфодіестерази-5, PDE5) та їх сукупного введення на морфометричні характеристики основних (пірамідних) клітин гіпокампа мишей. Флуоксетин (5 мг/кг), силденафіл (2 мг/кг) або комбінація цих агентів у зазначених дозах уводилися самцям мишей внутрішньоочеревинно щоденно протягом двох тижнів. Зрізи гіпокампа завтовшки 5 мкм забарвлювали гематоксиліном та еозином. Обидві речовини та їх комбінація не викликали значних змін розмірів пірамідний нейронів у зонах $C A 1, C A 2$ та зубчастої звивини (33), певна тенденція до зменшення зазначеного параметра спостерігалася після ін'єкцій флуоксетину в зоні $C A 1$. Сукупна дія флуоксетину та силденафілу призводила до істотного зменшення щільності пірамідних нейронів (їх середньої кількості з розрахунку на 10 мкм зрізу) у зоні $C A 1$ та 33. Обговорюються можливі механізми ефектів згаданих агентів. Доцільними є подальші дослідження особливостей взаємодії флуоксетину та силденафілу на морфологічні та фізіологічні характеристики клітин у різних підрозділах гіпокампа.

\section{REFERENCES}

1. J. E. Malberg and R. S. Duman, "Cell proliferation in adult hippocampus is decreased by inescapable stress: reversal by fluoxetine treatment," Neuropsychopharmacology, 28, No. 9, 1262-1271 (2003).

2. T. Hajszan, N. J. MacLusky, and C. Leranth, "Short-term treatment with the antidepressant fluoxetine triggers pyramidal dendritic spine synapse formation in rat hippocampus," Eur. J. Neurosci., 21, No. 5, 1299-1303 (2005).

3. J. Prickaerts, W. C. van Staveren, A. Sik, et al., "Effects of two selective phosphodiesterase type 5 inhibitors, sildenafil and vardenafil, on object recognition memory and hippocampal cyclic GMP levels in the rat," Neuroscience, 113, No. 2, 351361 (2002).

4. K. Rutten, J. D.Vente, A. Sik, et al., "The selective PDE5 inhibitor, sildenafil, improves object memory in Swiss mice and increases cGMP levels in hippocampal slices," Behav. Brain Res., 164, No. 1, 11-16 (2005).

5. U. Gómez-Pinedo, R. Rodrigo, O. Cauli, et al., "cGMP modulates stem cells differentiation to neurons in brain in vivo," Neuroscience, 165, No. 4, 12756-12786 (2010).

6. B. Chanrion, C. Mannoury la Cour, F. Bertaso, et al., "Physical interaction between the serotonin transporter and neuronal nitric oxide synthase underlies reciprocal modulation of their activity," Proc. Natl. Acad. Sci. USA., 104, No. 19, 8119-8124 (2007).

7. J. E. Malberg, A. J. Eisch, E. J. Nestler, and R. S. Duman, "Chronic antidepressant treatment increases neurogenesis in adult rat hippocampus," J. Neurosci., 20, No. 24, 9104-9110
(2000).

8. B. Czéh, M. Simon, B. Schmelting, et al., "Astroglial plasticity in the hippocampus is affected by chronic psychosocial stress and concomitant fluoxetine treatment," Neuropsychopharmacology, 31, No. 8, 1313-1326 (2006).

9. S. D. Norrholm and C. C. Ouimet, "Chronic fluoxetine administration to juvenile rats prevents age-associated dendritic spine proliferation in hippocampus," Brain Res., 883, No. 2, 205-215 (2000).

10. J. Tigges and T. R. Shantha, A Stereotaxic Brain Atlas of the Tree Shrew (Tupaia glis), Waverly Press, Baltimore, MD (1996)

11. O. F. O'Leary, X. Wu, and E. Castren, "Chronic fluoxetine treatment increases expression of synaptic proteins in the hippocampus of the ovariectomized rat: role of BDNF signalling," Psychoneuroendocrinology, 34, No. 3, 367-381 (2009).

12. N. Liebenberg, B. H. Harvey, L. Brand, and C. B. Brink, "Antidepressant-like properties of phosphodiesterase type 5 inhibitors and cholinergic dependency in a genetic rat model of depression," Behav. Pharmacol., 21, 540-547 (2010).

13. C. V. Romanini, A. P. Schiavon, E. D. Ferreira, et al., "Sildenafil prevents mortality and reduces hippocampal damage after permanent, stepwise, 4-vessel occlusion in rats," Brain Res. Bull., 81, No. 6, 631-640 (2010).

14. R. Zhang, Y. Wang, L. Zhang, et al., "Sildenafil (Viagra) induces neurogenesis and promotes functional recovery after stroke in rats," Stroke, 33, No. 11, 2675-2680 (2002).

15. W. W. Shen, Z. Urosevich, and D. O. Clayton, "Sildenafil in the treatment of female sexual dysfunction induced by selective serotonin reuptake inhibitors," J. Reprot. Med., 44, No. 6, 535-542 (1999).

16. M. M. Hosseini and H. Yarmohammadi, "Effect of fluoxetine alone and in combination with sildenafil in patients with premature ejaculation," Urol. Int., 79, No. 1, 28-32 (2007).

17. H. G. Nurnberg, P. L. Hensley, A. J. Gelenberg, et al., "Treatment of antidepressant-associated sexual dysfunction with sildenafil: a randomized controlled trial," J. Am. Med. Ass., 289, 56-64 (2003).

18. J. Zhang, X. Y. Huang, M. L. Ye, et al., "Neuronal nitric oxide synthase alteration accounts for the role of 5-HT1A receptor in modulating anxiety-related behaviors," J. Neurosci., 30, 2433 2441 (2010).

19. S. Uthayathas, S. S. Karuppagounder, B. M. Thrash, et al., "Versatile effects of sildenafil: recent pharmacological applications," Pharmacol. Reports, 59. No. 2, 150-163 (2007).

20. A. J. Gow, C. R. Farkouh, D. A. Munson, et al., "Biological significance of nitric oxide-mediated protein modifications," Am. J. Physiol. Lung Cell Mol. Physiol., 287, No. 2, 262-268 (2004)

21. C. B. Zhu, W. A. Hewlett, S. H. Francis, et al., "Stimulation of serotonin transport by the cyclic GMP phosphodiesterase-5 inhibitor sildenafil," Eur. J. Pharmacol., 504, Nos. 1/2, 1-6 (2004).

22. G. Wegener, V. Volke, and R. Rosenberg, "Endogenous nitric oxide decreases hippocampal levels of serotonin and dopamine in vivo," Br. J. Pharmacol., 130, No. 3, 575-580 (2000). 